\title{
Anti-inflammatory effect of Amomum xanthioides in a mouse atopic dermatitis model
}

\author{
YOUNG-AE CHOI ${ }^{1 *}$, JIN KYEONG CHOI $^{*}$, YONG HYUN JANG ${ }^{2 *}$, SOYOUNG LEE $^{3}$, \\ SANG-RAE LEE ${ }^{4}$, JUNG HO CHOI ${ }^{5}$, JEE HUN PARK ${ }^{5}$, TAE-YONG SHIN ${ }^{6}$ and SANG-HYUN KIM ${ }^{1}$ \\ ${ }^{1}$ Department of Pharmacology, Cell and Matrix Research Institute; ${ }^{2}$ Department of Dermatology, \\ School of Medicine, Kyungpook National University, Daegu 41944; ${ }^{3}$ Immunoregulatory Materials Research Center, \\ Korea Research Institute of Bioscience and Biotechnology, Jeongeup, Jeollabuk-do 56212; ${ }^{4}$ National Primate \\ Research Center, Korea Research Institute of Bioscience and Biotechnology, Cheongju, Chungcheongbuk-do 28116; \\ ${ }^{5}$ R\&D Center Pharmaceutical Laboratory, Korean Drug Co., Ltd., Seoul 06300; ${ }^{6}$ Department of Pharmacy, \\ College of Pharmacy, Woosuk University, Samrye, Jeollabuk-do 55338, Republic of Korea
}

Received June 26, 2017; Accepted August 31, 2017

DOI: $10.3892 / \mathrm{mmr} .2017 .7695$

\begin{abstract}
Atopic dermatitis (AD) is a chronic relapsing inflammatory skin disorder. The present study investigated the effects of Amomum xanthioides extract (AXE) on AD-like skin inflammation using a Dermatophagoides farinae extract (DFE) and 2,4-dinitrochlorobenzene (DNCB)-induced mouse AD model. Hematoxylin and eosin staining results demonstrated that repeated DFE/DNCB exposure markedly increased the thickening of the dermis and epidermis, in addition to the infiltration of eosinophils and mast cells. However, oral administration of AXE reduced these histopathological alterations in a dose-dependent manner. Elevated serum histamine, total and DFE-specific immunoglobulin E (IgE), and $\operatorname{IgG} 2 \mathrm{a}$ were also decreased by treatment with AXE. In addition, reverse transcription-quantitative polymerase chain reaction (RT-qPCR) results demonstrated that the mRNA expression of tumor necrosis factor (TNF)- $\alpha$, interferon (IFN) $-\gamma$, interleukin (IL)-4, IL-13, IL-31 and IL-17A was reduced in ear skin following AXE administration in AD mice. Fluorescence-activated cell sorting demonstrated that the population of $\mathrm{CD}^{+} / \mathrm{IL}-4^{+}, \mathrm{CD} 4^{+} / \mathrm{IFN}-\gamma^{+}$and $\mathrm{CD} 4^{+} / \mathrm{IL}-17 \mathrm{~A}^{+}$
\end{abstract}

Correspondence to: Professor Sang-Hyun Kim, Department of Pharmacology, Cell and Matrix Research Institute, School of Medicine, Kyungpook National University, 680 Gukchaebosang-ro, Jung-gu, Daegu 41944, Republic of Korea

E-mail: shkim72@knu.ac.kr

Professor Tae-Yong Shin, Department of Pharmacy, College of Pharmacy, Woosuk University, 443 Samrye-ro, Samrye, Jeollabuk-do 55338, Republic of Korea

E-mail: tyshin@woosuk.ac.kr

*Contributed equally

Key words: atopic dermatitis, Amomum xanthioides, keratinocyte, house dust mite, histamine cells in draining lymph nodes was also significantly decreased in AXE-treated mice compared with AD mice without AXE treatment. Furthermore, keratinocytes that were stimulated with TNF- $\alpha$ and IFN- $\gamma$ exhibited increased gene expression of pro-inflammatory cytokines and chemokines, including TNF- $\alpha$, IL-1 $\beta$, IL-6, IL-8, C-C motif chemokine ligand (CCL)17 and CCL22, as determined by RT-qPCR. However, upregulation of these genes was reduced by AXE pretreatment. Based on these results, we hypothesize that AXE may be useful in the treatment of allergic skin inflammation, particularly AD.

\section{Introduction}

Atopic dermatitis (AD) is a pruritic and chronic inflammatory skin disease caused by dysfunction of the skin barrier and immune response. Initially, skin dysfunction may be caused by increased protease activity, irritant exposure or genetic mutation (1). Disturbed skin tissues exhibit an increased permeability to external antigens or allergens, an increased release of innate immune cytokines from keratinocytes and increased infiltration of type 2 helper (Th2) T cells (2). Infiltrated Th2 cells secrete various inflammatory cytokines, including interleukin (IL)-4, IL-5 and IL-13, which are considered to increase immunoglobulin E (IgE) levels. Th2-promoted pro-inflammatory mediators further impair epidermal differentiation and integrity, and subsequently induce the release of pro-inflammatory and pruritogenic mediators by keratinocytes (2).

AD develops in early childhood up to five years old and is observed in $60 \%$ of adults who have a personal family history of similar skin diseases or asthma during childhood (3). Methods of treating this disorder generally include the application of topical steroids or antibiotics and general skin care. As the number of available treatments is limited and several side effects are reported, certain patients opt for alternative treatments such as natural products $(4,5)$. Various pharmacological compounds from natural products have been developed that 
may have the potential to treat various symptoms in chronic diseases including atopic dermatitis (AD) (6).

Amomum xanthioides is the seed of Amomum villosum Lour, which is grown throughout Asia. The seed of A. xanthioides has traditionally been used to treat indigestion, diarrhea, flatulence, toothache and sepsis in China and Vietnam (7). In addition, the fruit is effective against asthma and also functions as an antiemetic agent (7). Various studies have demonstrated that the seed extract of $A$. xanthioides (AXE) exerts various pharmacological effects, including hepatoprotective and anti-gastritis effects, and the prevention of diabetes mellitus $(8,9)$. Furthermore, our previous studies demonstrated that seed AXE inhibited immediate-type hypersensitivity by reducing mast cell degranulation $(10,11)$. The present study investigated the effects of AXE on allergic skin inflammation, specifically $\mathrm{AD}$, and the underlying mechanism of action.

\section{Materials and methods}

Animals. Six-week-old BALB/c mice (female, $20 \mathrm{~g}$ ) were purchased from Japan SLC, Inc (Hamamatsu, Japan). A total of 30 mice were housed with 5-10 mice per cage in a laminar air flow room and were maintained at a temperature of $22 \pm 2^{\circ} \mathrm{C}$ with a relative humidity of $55 \pm 5 \%$ throughout the study. The food and water were provided ad libitum, and mice were kept on a 12-h light/12-h dark cycle. The care and treatment of the mice were in accordance with the guidelines established by the Public Health Service Policy on the Humane Care and Use of Laboratory Animals (Kyungpook National University, Daegu, Republic of Korea) and was approved by the Institutional Animal Care and Use Committee in Kyungpook National University, Daegu, Republic of Korea.

Preparation of $A X E$. The AXE was prepared as previously described (11). Briefly, A. xanthioides seeds were purchased from Bohwa Dang (Jeonju, Korea) and identified by Dr D.K. Kim at the College of Pharmacy, Woosuk University (Samrye, Korea). A voucher specimen (no. WSP-16-04) was deposited at the Herbarium of Woosuk University. Seeds were ground $(1,000 \mathrm{rpm}$ for $30 \mathrm{sec})$ at room temperature using a Micro Hammer-Cutter Mill (Culatti AG, Zurich, Switzerland). The particle size after grinding was $0.5-2 \mathrm{~mm}$. The plant sample $(60 \mathrm{~g})$ was extracted twice with purified water $(500 \mathrm{ml})$ at $70^{\circ} \mathrm{C}$ for $5 \mathrm{~h}$ in a water bath. The extract was filtered through Whatman grade 1 filter paper and the filtrate was lyophilized using $0.45 \mu \mathrm{m}$ syringe filters. The dried extract yield from crude materials was $\sim 5.2 \%$. The dried extract was dissolved in saline or Tyrode's buffer A (10 mM HEPES, $130 \mathrm{mM} \mathrm{NaCl}$, $5 \mathrm{mM} \mathrm{KCl}, 1.4 \mathrm{mM} \mathrm{CaCl}_{2}, 1 \mathrm{mM} \mathrm{MgCl}{ }_{2}, 5.6 \mathrm{mM}$ glucose and $0.1 \%$ bovine serum albumin (Affymetrix; Thermo Fisher Scientific, Inc., Waltham, MA, USA) prior to use.

Drugs and chemicals. All reagents were purchased from Sigma-Aldrich; Merck KGaA (Darmstadt, Germany) unless otherwise stated. House dust mite (Dermatophagoides farinae) extract (DFE; Greer Laboratories, Inc., Lenoir, NC, USA) was used as an antigen and 2,4-dinitrochlorobenzene (DNCB) was used as a sensitizer to induce AD-like skin inflammation. Freeze-dried crude DFE powder was dissolved in PBS containing $0.5 \%$ Tween-20. DNCB (1\%) was dissolved in an acetone/olive oil (1:3) solution. Recombinant TNF- $\alpha$ and IFN- $\gamma$ were purchased from R\&D systems, Inc. (Minneapolis, MN, USA).

Cell culture and viability. A human keratinocyte cell line, HaCaT (American Type Culture Collection, Manassas, VA, USA), was maintained in Dulbecco's modified Eagle's medium (Thermo Fisher Scientific, Inc.) supplemented with $10 \%$ fetal bovine serum (Thermo Fisher Scientific, Inc) and antibiotics (100 U/ml penicillin $\mathrm{G}$ and $100 \mu \mathrm{g} / \mathrm{ml}$ streptomycin) at $37^{\circ} \mathrm{C}$ in 90-95\% humidity and $5 \% \mathrm{CO}_{2}$. Cell viability was determined using a MTT assay. HaCaT cells were treated with various concentration of $\operatorname{AXE}(0,0.01,0.1,1,10$ and $100 \mu \mathrm{g} / \mathrm{ml})$ and incubated for $24 \mathrm{~h}$ at $37^{\circ} \mathrm{C}$ in $5 \% \mathrm{CO}_{2}$. Then, MTT $(5 \mathrm{mg} / \mathrm{ml})$ was added to each sample well and incubated for $2 \mathrm{~h}$ at $37^{\circ} \mathrm{C}$. Dimethyl sulfoxide was added to dissolve the formazan crystals. The absorbance of each sample was at a wavelength of $570 \mathrm{~nm}$ compared with the control and expressed as a percentage.

Induction of $A D$-like skin inflammation in the mouse ear. The induction of AD-like skin inflammation by DFE and DNCB was performed using methods based on our previous research (12). Total 30 mice were divided into the following six groups ( $n=5$ each group): Vehicle (mice were treated only with PBS); DFE/DNCB + vehicle; DFE/DNCB + AXE (2, 10 and $50 \mathrm{mg} / \mathrm{kg}$ ) and tacrolimus (Tac; $1 \mathrm{mg} / \mathrm{kg}$ ) (Sigma-Aldrich; Merck KGaA). The surfaces of both ear lobes were stripped very gently using surgical tape to remove foreign matter or scabbing. After stripping, $20 \mu \mathrm{l}$ DNCB (1\%) was applied to each ear, which was followed by $20 \mu \mathrm{l}$ DFE (10 mg/ml) 4 days later. Treatment with DFE/DNCB was repeated once a week alternatively for 4 weeks. At 1 week after the first DFE/DNCB treatment, AXE or Tac was orally administered 5 times weekly between days 7 and 27. Ear thickness was measured $24 \mathrm{~h}$ after DFE or DNCB application with a dial thickness gauge.

On day 28 , blood samples were collected via celiac artery puncture. Whole blood was incubated at $4^{\circ} \mathrm{C}$ overnight, centrifuged at $400 \mathrm{x} \mathrm{g}$ for $10 \mathrm{~min}$ at $4^{\circ} \mathrm{C}$, and serum was collected. After mice were sacrificed, ears were removed and used for histopathological analysis. IgG2a levels were measured using an ELISA kit (cat. no. 552576, BD Biosciences, Franklin Lakes, NJ, USA). Total IgE and DFE-specific IgE level were assayed with the same kit (cat. no. 555248). Total IgE levels were measured by concentration calculation. Mite-specific IgE levels were detected as optical density values.

Histological observations. The ears were fixed with $10 \%$ formaldehyde for one week at room temperature and embedded in paraffin. Sections of $5 \mu \mathrm{m}$ thickness were stained with hematoxylin solution for $5 \mathrm{~min}$ and eosin solution for $1 \mathrm{~min}$ at room temperature. Cellular infiltration of eosinophils and thickening of the epidermis and dermis were observed via light microscopy. Eosinophils were also counted from 10 different fields at a magnification $x 400$ in a blinded manner. Dermal thickness in H\&E-stained sections was visualized and analyzed at a magnification $x 200$. Thickness was measured from five randomly selected fields from each sample. For measurement of mast cell infiltration, skin sections were stained with $0.1 \%$ toluidine blue solution for 2-3 $\mathrm{min}$ at room temperature and 
mast cells from 10 different fields were counted at a magnification $\mathrm{x} 400$ in a blinded manner.

Histamine assay. Histamine content was measured via the $o$-phthaldialdehyde spectrofluorometric procedure based on the method described by a previous report (13). Blood from the mice was centrifuged at $400 \mathrm{x}$ g for $10 \mathrm{~min}$ at $4^{\circ} \mathrm{C}$ and serum was withdrawn to measure histamine content. For serum histamine assay, $50 \mu 1$ serum was used. Fluorescence was measured on an LS-50B fluorescence spectrometer (PerkinElmer, Inc., Waltham, MA, USA) using $355 \mathrm{~nm}$ excitation and $450 \mathrm{~nm}$ emission filters.

Fluorescence-activated cell sorting. At the end of the experiment, mice were euthanized with $\mathrm{CO}_{2}$ and both auricular lymph nodes were collected from each mouse. Auricular lymph nodes were ground using $70 \mu \mathrm{m}$ nylon cell strainers to isolate single cells. Cells were subsequently stained using a Mouse Th1/Th2/Th17 phenotyping kit (BD Biosciences) according to the manufacturer's protocol, and fluorescence intensity was detected using a FACSCalibur flow cytometer (BD Biosciences). Population of cells was analyzed by BD CellQuest ${ }^{\mathrm{TM}}$ Pro software (version 5.1, BD Biosciences).

Reverse transcription-quantitative polymerase chain reaction $(R T-q P C R)$. For the quantification of cytokine expression, qPCR was performed using the TP850 Thermal Cycler Dice Real Time System (Takara Bio, Inc., Otsu, Japan) according to the manufacturer's protocol. At the end of the in vivo experimental period, the ears were excised and total RNA was isolated. Total RNA was isolated using RNAiso Plus (Takara Bio, Inc.). For the in vitro analysis, $\mathrm{HaCaT}$ cells were pretreated with $0,0.1$, 1 and $10 \mu \mathrm{g} / \mathrm{ml} \mathrm{AXE}$ or $10 \mu \mathrm{g} / \mathrm{ml}$ Tac for $1 \mathrm{~h}$ at $37^{\circ} \mathrm{C}$, and subsequently stimulated with TNF- $\alpha(10 \mathrm{ng} / \mathrm{ml})$ and IFN- $\gamma$ $(10 \mathrm{ng} / \mathrm{ml})$ for $6 \mathrm{~h}$ at $37^{\circ} \mathrm{C}$. Total cellular RNA was isolated from cells ( $2 \times 10^{5}$ cells/24-well plate) according to a method previously described (14). Complementary (c)DNA was synthesized with $1 \mu \mathrm{g}$ of total RNA under condition of $1 \mathrm{~h}$ at $45^{\circ} \mathrm{C}$ and $5 \mathrm{~min}$ at $95^{\circ} \mathrm{C}$ using Maxime RT PreMix Kit (Intron Biotechnology, Inc., Seongnam, Korea). A total of $2 \mu \mathrm{l} \mathrm{cDNA} \mathrm{(100} \mathrm{ng),} 1 \mu \mathrm{l}$ sense and antisense primer solution $(0.4 \mu \mathrm{M}), 12.5 \mu \mathrm{l} \mathrm{SYBR}$

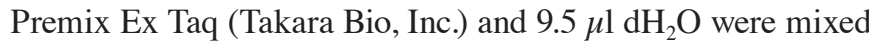
together to obtain a $25 \mu \mathrm{l}$ reaction mixture in each reaction tube. The relative transcription levels of the mRNAs were calculated according to the $2^{-\Delta \Delta \mathrm{Cq}}$ method (15). $\beta$-actin was used as an internal control. The primers used are shown in Table I. The conditions for amplification of DNA were $95^{\circ} \mathrm{C}$ for $30 \mathrm{sec}$, 45 cycles of $95^{\circ} \mathrm{C}$ for $5 \mathrm{sec}$, and $60^{\circ} \mathrm{C}$ for $30 \mathrm{sec}$. A melting curve analysis was done after amplification. Normalization and quantification of mRNA expression were performed using the TP850 software supplied by the manufacturer.

Nuclear protein extraction. HaCaT cells were pretreated with AXE for $1 \mathrm{~h}$, and then stimulated with TNF- $\alpha(10 \mathrm{ng} / \mathrm{ml})$ and IFN- $\gamma(10 \mathrm{ng} / \mathrm{ml})$ for $30 \mathrm{~min}$. After stimulation, cells ( $1 \times 10^{6}$ cells $/ 6$-well plate) were washed in $1 \mathrm{ml}$ of ice-cold PBS, centrifuged at $1,200 \times \mathrm{g}$ for $5 \mathrm{~min}$ at $4^{\circ} \mathrm{C}$, resuspended in $400 \mu \mathrm{l}$ of ice-cold hypotonic buffer (10 mM HEPES, $2 \mathrm{mM} \mathrm{MgCl}$, $0.1 \mathrm{mM}$ EDTA, $10 \mathrm{mM} \mathrm{KCl,} 1 \mathrm{mM}$ DTT, $0.5 \mathrm{mM}$ PMSF, $\mathrm{pH}$ 7.9), left on ice for $10 \mathrm{~min}$, vortexed, and centrifuged at
$5,000 \times \mathrm{g}$ for $5 \mathrm{~min}$ at $4^{\circ} \mathrm{C}$. Pelleted nuclei were resuspended in $50 \mu \mathrm{l}$ of ice-cold saline buffer (50 mM HEPES/KOH, $50 \mathrm{mM}$ $\mathrm{KCl}, 300 \mathrm{mM} \mathrm{NaCl}, 0.1 \mathrm{mM}$ EDTA, 10\% glycerol, $1 \mathrm{mM}$ DTT, $0.5 \mathrm{mM}$ PMSF, pH 7.9), left on ice for $20 \mathrm{~min}$, vortexed, centrifuged at $15,000 \mathrm{x} \mathrm{g}$ for $5 \mathrm{~min}$ at $4^{\circ} \mathrm{C}$, and supernatant was collected.

Western blot analysis. Samples for western blotting were prepared as previously described (14). HaCaT cells (1x10 6 cells/6-well plate) were stimulated for $20 \mathrm{~min}$ with TNF- $\alpha(10 \mathrm{ng} / \mathrm{ml})$ and IFN- $\gamma(10 \mathrm{ng} / \mathrm{ml})$ for extracellular signal-regulated kinase (ERK) and p38 mitogen-activated protein kinases (MAPKs) and signal transducer and activator of transcription 1 (STAT1), and $30 \mathrm{~min}$ for nuclear factor- $\kappa \mathrm{B}$ (NF- $\mathrm{kB}$ ) after pretreatment with $10 \mu \mathrm{g} / \mathrm{ml}$ AXE or $10 \mu \mathrm{g} / \mathrm{ml}$ Tac for $1 \mathrm{~h}$. Whole-cell extracts were prepared by washing cells twice with ice-cold PBS and incubating them in lysis buffer [20 mM Tris (pH 7.4), $137 \mathrm{mM} \mathrm{NaCl,} 2 \mathrm{mM}$ EDTA, $10 \%$ glycerol, $1 \%$ Triton X-100, $100 \mu \mathrm{M}$ DTT] with the addition of phosphatase inhibitor cocktail (Roche Diagnostics, Indianapolis, IN, USA) for $30 \mathrm{~min}$ at $4^{\circ} \mathrm{C}$. The lysates were collected by centrifugation at $13,000 \mathrm{x}$ g for $15 \mathrm{~min}$ at $4^{\circ} \mathrm{C}$, and protein quantification was performed with a Bradford protein assay kit (Bio-Rad, Hercules, CA, USA). For western blot analysis, $30 \mu \mathrm{g}$ of total protein was separated using 8-12\% sodium dodecyl sulfate polyacrylamide gels and transferred to nitrocellulose membranes (Pall Life Sciences, Port Washington, NY, USA). The membranes were stained with reversible Ponceau S stain for 10-20 sec at room temperature to ascertain equal loading of samples in the gel. All blots were blocked in $3 \%$ blocking buffer [3\% w/v skim milk, $0.1 \%$ Tween-20, Tris-buffered saline $(\mathrm{pH} 7.4)]$ at room temperature for $1 \mathrm{~h}$ and incubated in primary antibody (1:1,000 dilution) at $4^{\circ} \mathrm{C}$ for overnight. Then, secondary antibody (1:2,000 dilution) were incubated at room temperature for $1 \mathrm{~h}$. Detection was performed using an enhanced chemiluminescence detection kit (GE Healthcare, Chicago, IL, USA). $\beta$-actin and lamin B were used as internal loading controls for cytosolic and nuclear extraction, respectively. Phospho-ERK (Thr202/Tyr204; cat. no. 9101), phospho-p38 MAPK (Tyr180/Tyr182; cat. no. 9211), phospho-STAT1 (Tyr701; cat. no. 9171), ERK (ERK1/2; cat. no. 9102), p38 MAPK (cat. no. 9212) and STAT1 (cat. no. 9172) were from Cell Signaling Technology Inc. (Danvers, MA, USA). NF- $\kappa$ B p65 (cat. no. sc-109), I $\kappa-\alpha$ (cat. no. sc-371), lamin B (cat. no. sc-6217), $\beta$-actin (cat. no. sc-8432), and horseradish peroxidase-linked anti-rabbit IgG (cat. no. sc-2004) antibodies were from Santa Cruz Biotechnology, Inc. (Dallas, TX, USA).

Statistical analysis. Statistical analyses were performed using GraphPad Prism 7 (La Jolla, CA, USA). Treatment effects were analyzed using one-way analysis of variance followed by Dunnett's test. Data are presented as the mean \pm standard error. $\mathrm{P}<0.05$ was considered to indicate a statistically significant difference.

\section{Results}

Effects of AXE on ear thickness and histopathological changes in AD-like skin inflammation. To investigate the 
Table I. Sequences of oligonucleotide primers.

\begin{tabular}{|c|c|c|c|}
\hline Mouse & Primer sequence (5'-3') & Position & GenBank accession number \\
\hline \multicolumn{4}{|l|}{ TNF- $\alpha$} \\
\hline Forward & GGCAGGTCTACTTTGGAGTCATTGC & 796-1,095 & NM_001278601.1 \\
\hline Reverse & ACATTCGAGGCTCCAGTGAATTCG G & & \\
\hline \multicolumn{4}{|l|}{ IFN- $\gamma$} \\
\hline Forward & TCAAGTGGCATAGATGTGGAAGAA & 224-315 & NM_008337.4 \\
\hline Reverse & TGGCTCTGCAGGATTTTCATG & & \\
\hline \multicolumn{4}{|l|}{ IL-4 } \\
\hline Forward & ACAGGAGAAGGGACGCCAT & $180-274$ & NM_021283.2 \\
\hline Reverse & GAAGCCGTACAGACGAGCTCA & & \\
\hline \multicolumn{4}{|l|}{ IL-13 } \\
\hline Forward & GCAGCATGGTATGGAGTGTG & $226-451$ & NM_008355.3 \\
\hline Reverse & TGGCGAAACAGTTGCTTTGT & & \\
\hline \multicolumn{4}{|l|}{ IL-31 } \\
\hline Forward & TCGGTCATCATAGCACATCTGGA & $308-637$ & NM_029594.1 \\
\hline Reverse & GCACAGTCCCTTTGGAGTTAAGTC & & \\
\hline \multicolumn{4}{|l|}{ IL-17A } \\
\hline Forward & TCCCTCTGTGATCTGGGAAG & $321-474$ & NM_010552.3 \\
\hline Reverse & CTCGACCCTGAAAGTGAAGG & & \\
\hline \multicolumn{4}{|l|}{$\beta$-actin } \\
\hline Forward & TAGACTTCGAGCAGGAGATG & $771-1,092$ & NM_007393.5 \\
\hline Reverse & TTGATCTTCATGGTGCTAGG & & \\
\hline Human & Primer sequence $\left(5^{\prime}-3^{\prime}\right)$ & Position & GenBank accession number \\
\hline \multicolumn{4}{|l|}{ TNF- $\alpha$} \\
\hline Forward & CCTACCAGACCAAGGTCAAC & $660-937$ & NM_000594.3 \\
\hline Reverse & AGGGGGTAATAAAGGGATTG & & \\
\hline \multicolumn{4}{|l|}{ IL-1 $\beta$} \\
\hline Forward & GCTGATGGCCCTAAACAGATGAA & $163-271$ & NM_000576.2 \\
\hline Reverse & TGAAGCCCTTGCTGTAGTGGTA & & \\
\hline \multicolumn{4}{|l|}{ IL-6 } \\
\hline Forward & AAAGAGGCACTGGCAGAAAA & $365-776$ & NM_000600.4 \\
\hline Reverse & ATCTGAGGTGCCCATGCTAC & & \\
\hline \multicolumn{4}{|l|}{ CCL17 } \\
\hline Forward & ACTGCTCCAGGGATGCCATCGTTT & $296-565$ & NM_002987.2 \\
\hline Reverse & ACAAGGGGATGGGATCTCCCTCAC & & \\
\hline \multicolumn{4}{|l|}{ CCL22 } \\
\hline Forward & AGGACAGAGCATGGCTCGCCTACA & $25-386$ & NM_002990.4 \\
\hline Reverse & TAATGGCAGGGAGGTAGGGCTCCT & & \\
\hline \multicolumn{4}{|l|}{$\beta$-actin } \\
\hline Forward & GGACTTCGAGCAAGAGATGG & $747-980$ & NM_001101.3 \\
\hline Reverse & AGCACTGTGTTGGCGTACAG & & \\
\hline
\end{tabular}

effects of AXE on AD-like skin inflammation, AXE was orally administered to BALB/c mice 5 times weekly from days 7 to 27. Repeated application of DFE/DNCB on the ear lobes of mice increased ear thickness, swelling, reddening and scaling of the skin. Ear thickening was unaffected until 1 week after initial oral administration of AXE (2,
10 and $50 \mathrm{mg} / \mathrm{kg}$ ). Thereafter, thickening was suppressed in a dose- and time-dependent manner by AXE (Fig. 1A). Ear photographs at the end of the experiment demonstrated the amelioration of the skin lesion, including swelling and reddening, by AXE treatment (Fig. 1B). Tac, also termed FK-506 or fujimycin, is an immunosuppressive drug used for 
A

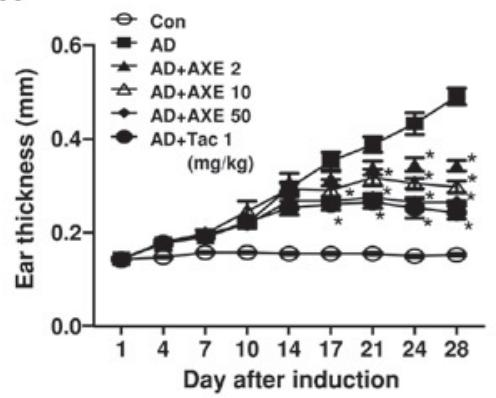

B

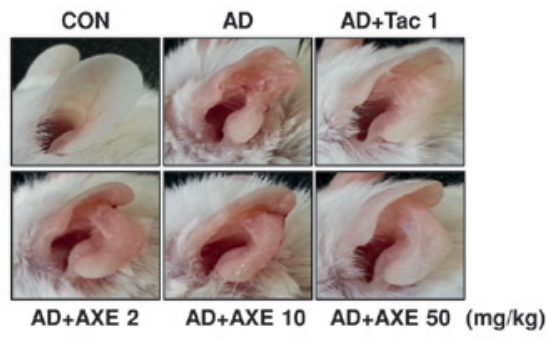

C

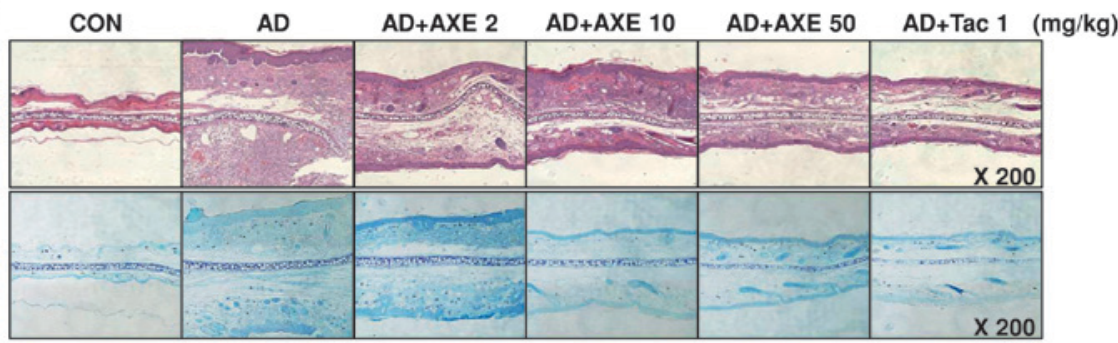

D

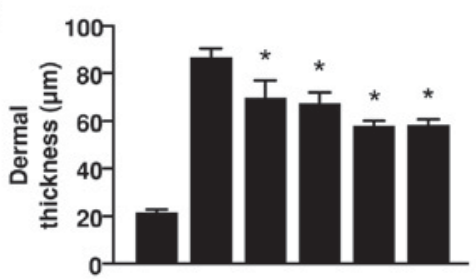

$\mathbf{F}$

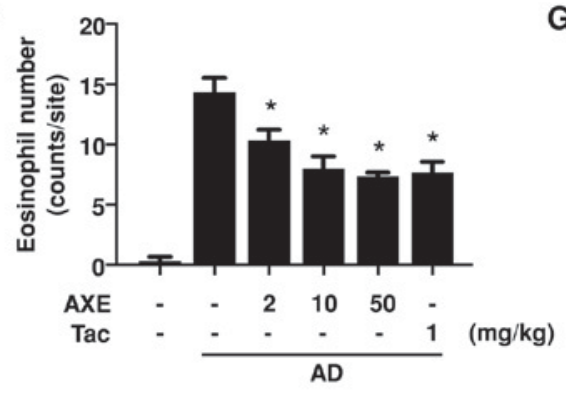

E

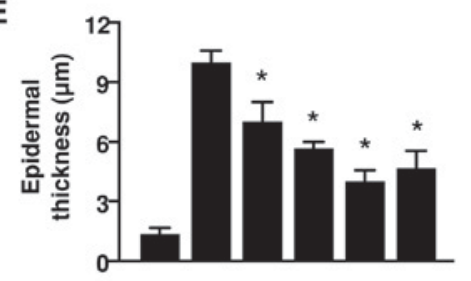

G

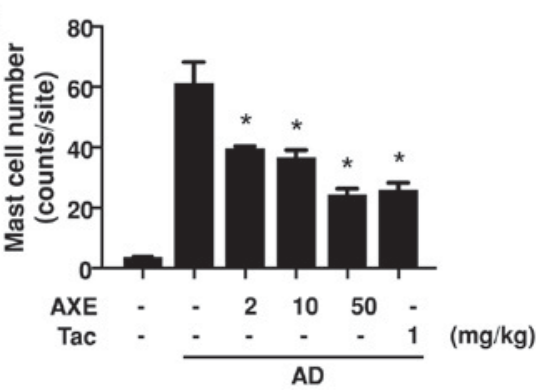

Figure 1. Effects of AXE on DFE/DNCB-induced AD mice. (A) To measure the effects of AXE (2, 10 and $50 \mathrm{mg} / \mathrm{kg})$ or Tac $(1 \mathrm{mg} / \mathrm{kg})$ on DFE/DNCB-induced $\mathrm{AD}$, ear thickness was measured $24 \mathrm{~h}$ after DFE or DNCB application with a dial thickness gauge. (B) Gross observation of morphological recovery at day 28. (C) Ear tissues were stained with H\&E or toluidine blue for histological analysis and the determination of dermal and epidermal thickness, and eosinophil and mast cell infiltration. Original magnification, x200. (D) Dermal and (E) epidermal thickness. Number of (F) eosinophils and (G) mast cells. Data are presented as the mean \pm standard error of the mean of five determinants. "P $<0.05$ vs. AD group. AXE, Amomum xanthioides extract; DFE, Dermatophagoides farinae extract; $\mathrm{DNCB}$, dinitrochlorobenzene; $\mathrm{AD}$, atopic dermatitis; Tac, tacrolimus; CON, control.

the treatment of inflammatory skin diseases such as AD and psoriasis. It was used as a positive control.

To analyze the effects of AXE on skin hypertrophy and infiltration of eosinophils and mast cells, which are important effector cells in $\mathrm{AD}$, tissue sections of ears were stained with $\mathrm{H} \& \mathrm{E}$ or toluidine blue (Fig. 1C). Quantitative values based on microscopic observations were analyzed (Fig. 1D-G). Compared with the control, repeated DFE/DNCB exposure caused a marked increase in the thickening of the dermis and epidermis, in addition to the infiltration of eosinophils and mast cells. However, oral administration of AXE reduced these histopathological changes in a dose-dependent manner (Fig. 1D-G).

Effect of AXE on serum histamine and Ig levels. To evaluate the serum levels of histamine and Igs in AD, serum was isolated following blood collection. Excessive production of histamine, a representative symptom of $\mathrm{AD}$, was detected in DFE/DNCB-sensitized mice (Fig. 2A). In addition, elevation of total IgE, DFE-specific IgE and IgG2a (Fig. 2B-D) was also observed in the DFE/DNCB-sensitized mice. These increased levels of histamine and Igs were significantly decreased following AXE application.

Effects of AXE on the polarization of Tlymphocytes and expression of cytokines in the ear tissue of $A D$ mice. The progression of $\mathrm{AD}$ is characterized by an alteration in the polarization of the T cell population, particularly that of Th1, Th2 and Th17 cells (16). To assess alterations in $\mathrm{T}$ lymphocyte polarization, single cells from auricular lymph nodes were isolated and analyzed using specific antibodies for signature cytokines 
A

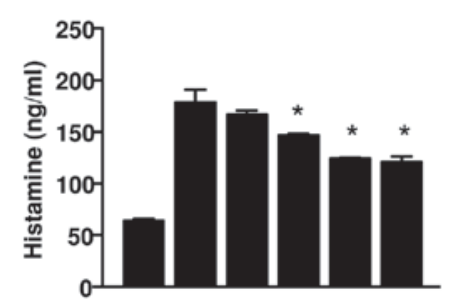

C

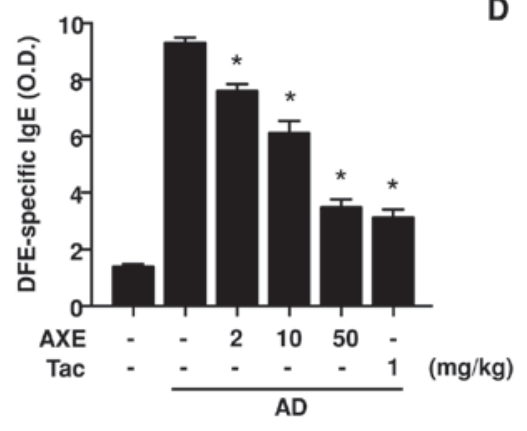

B
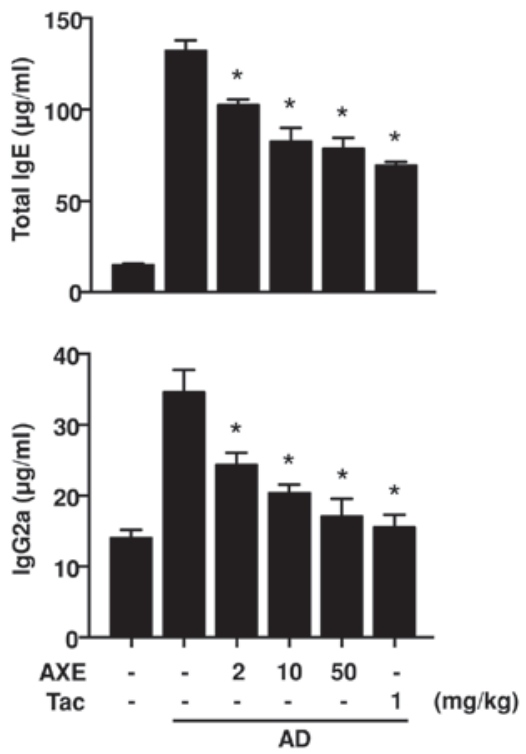

Figure 2. Levels of (A) serum histamine and (B-D) Igs in DFE/DNCB-induced AD mice. Blood samples from vehicle, DFE/DNCB + vehicle, and DFE/DNCB $+\operatorname{AXE}(2,10$ and $50 \mathrm{mg} / \mathrm{kg})$ or Tac $(1 \mathrm{mg} / \mathrm{kg})$ groups were obtained from the celiac artery at day 28 , and serum was isolated. Serum histamine and Igs were quantified by ELISA. Data are presented as the mean \pm standard error of the mean of five determinants. " $\mathrm{P}<0.05$ vs. AD group. Ig, immunoglobulin; AD, atopic dermatitis; DFE, Dermatophagoides farinae extract; DNCB, dinitrochlorobenzene; AXE, Amomum xanthioides extract; Tac, tacrolimus; O.D., optical density.

expressed by polarized lymphocytes, including IFN- $\gamma$ for Th1, IL-4 for Th2 and IL-17A for Th17 (Fig. 3). The results demonstrated that populations of $\mathrm{CD} 4^{+} / \mathrm{IFN}-\gamma^{+}, \mathrm{CD} 4^{+} / \mathrm{IL}-4^{+}$and $\mathrm{CD}^{+} / \mathrm{IL}-17 \mathrm{~A}^{+}$were increased in the DFE/DNCB-sensitized mice, and were dose-dependently decreased following AXE treatment.

In $\mathrm{AD}$, infiltrated immune cells, including lymphocytes and resident keratinocytes, continuously interact via the production of various cytokines, and thus exacerbate the disease (2). To assess the gene expression of cytokines in AD skin, RNA was isolated from ear tissue and qPCR was performed. Repeated application of DFE/DNCB increased the expression levels of IL-4, IL-13, IL-31, TNF- $\alpha$, IFN- $\gamma$ and IL-17A. However, treatment with AXE significantly reduced the expression of these cytokines at certain doses (Fig. 4).

Effects of AXE on the activation of keratinocytes. In AD, keratinocytes are an important source of cytokines that accelerate chronic, self-amplifying loops of immune activation. In skin inflammation, the increased production of TNF- $\alpha$ and IFN- $\gamma$ by keratinocytes promotes the amplification of the inflammatory response. TNF- $\alpha$ and IFN- $\gamma$ stimulate the synthesis and secretion of various inflammatory mediators by keratinocytes $(14,17)$. To determine the effect of AXE on the production of inflammatory cytokines and its signaling mechanism, HaCaT cells were stimulated with TNF- $\alpha / \mathrm{IFN}-\gamma$ with or without pretreatment with AXE (Fig. 5). Treatment with TNF- $\alpha /$ IFN- $\gamma$ promoted the gene expression of the pro-inflammatory cytokines, such as TNF- $\alpha$, IL-1 $\beta$, IL-6 and IL-8, CCL17 and CCL22. These increased levels were reduced by pretreatment with AXE (Fig. 5A). Cell viability of $\mathrm{HaCaT}$ cells was unaffected by AXE concentrations of up to $100 \mu \mathrm{g} / \mathrm{ml}$ (Fig. 5B).

To investigate the mechanism responsible for the inhibitory effects of AXE on the expression of cytokines and
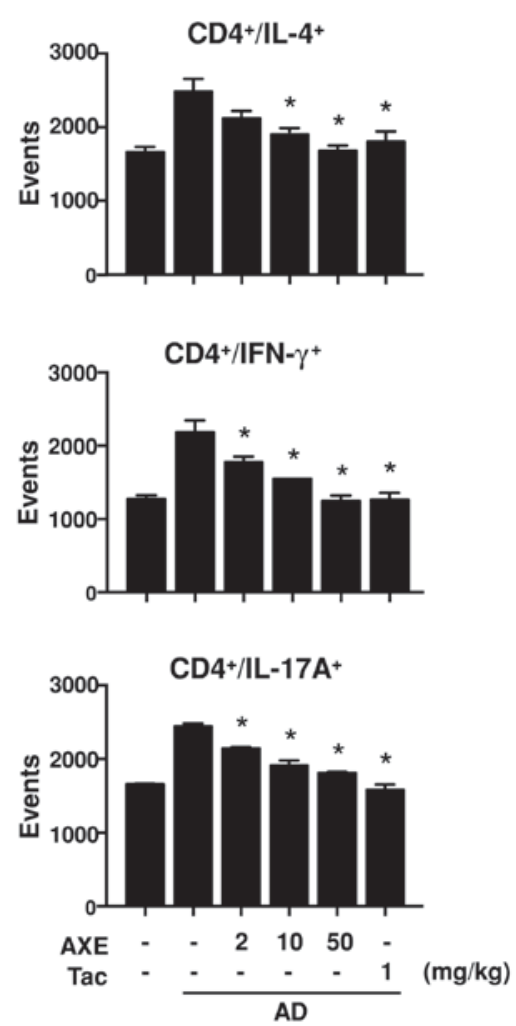

Figure 3. Phenotypes of T lymphocytes in the auricular lymph nodes of DFE/DNCB-induced AD mice. The number of $\mathrm{CD} 4^{+} / \mathrm{IL}-4^{+}, \mathrm{CD} 4^{+} / \mathrm{IFN}-\gamma^{+}$ and $\mathrm{CD} 4^{+} / \mathrm{IL}-17 \mathrm{~A}^{+}$cells was detected by fluorescence-activated cell sorting analysis. Data are presented as the mean \pm standard error of the mean of five determinants. " $\mathrm{P}<0.05$ vs. AD group $\mathrm{AD}$, atopic dermatitis; IL, interleukin; IFN, interferon; AXE, Amomum xanthioides extract; Tac, tacrolimus.

chemokines in HaCaT cells, the activation of MAPKs, STAT1, $\mathrm{IkB} \alpha$ and $\mathrm{NF}-\kappa \mathrm{B}$, which regulate the expression of cytokines and chemokines, was analyzed by Western blot (Fig. 5C). 

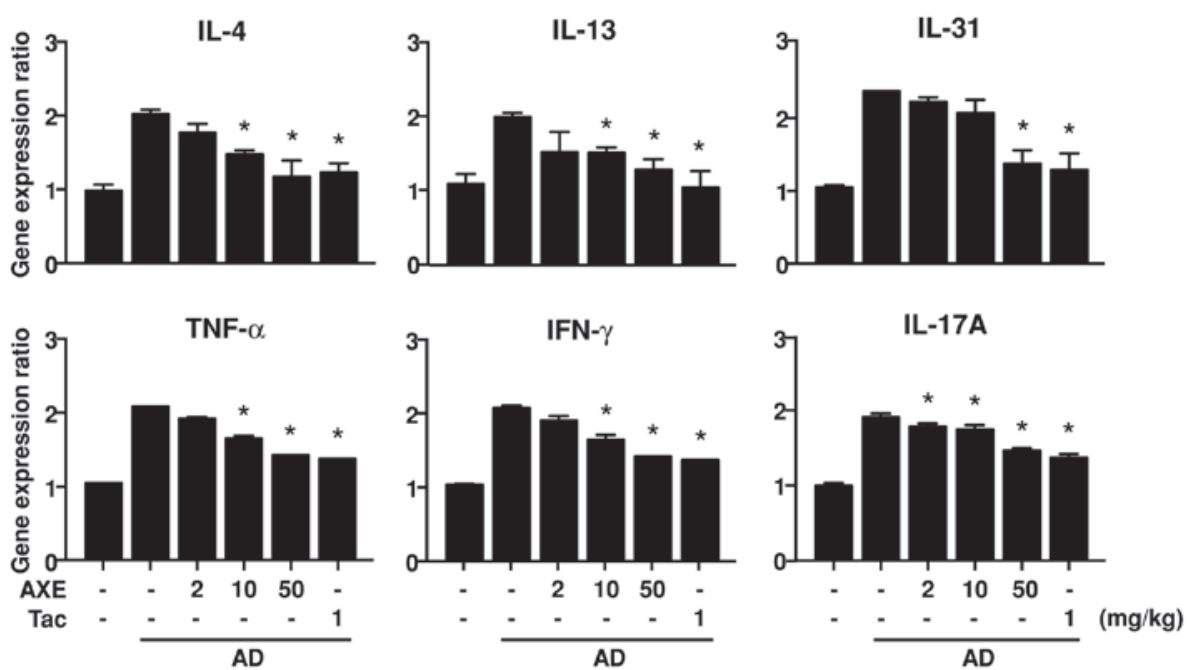

Figure 4. mRNA expression of cytokines in the ear tissue of DFE/DNCB-induced AD mice. Ears were excised at day 28 and total RNA was isolated, then reverse transcription-quantitative polymerase chain reaction was performed. Data are presented as the mean \pm standard error of the mean of five determinants. ${ }^{*} \mathrm{P}<0.05$ vs. AD group. AD, atopic dermatitis; IL, interleukin; TNF, tumor necrosis factor; IFN, interferon; AXE, Amomum xanthioides extract; Tac, tacrolimus.

A

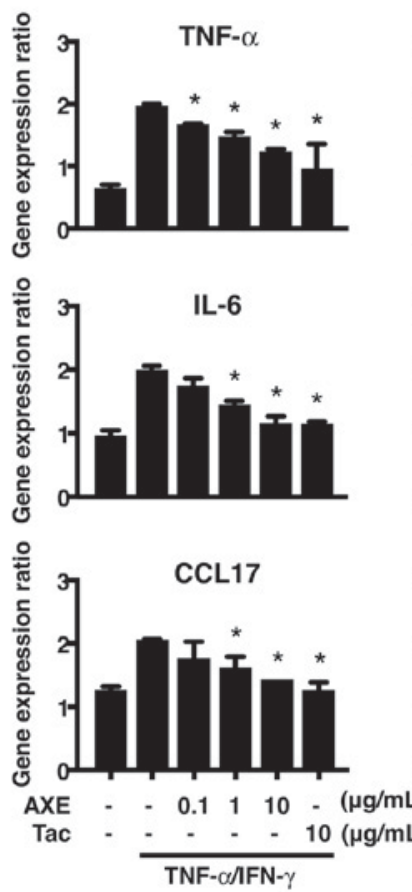

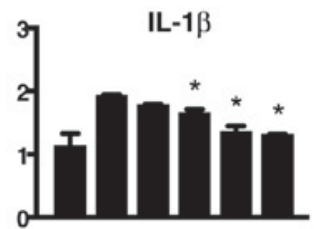

IL-8
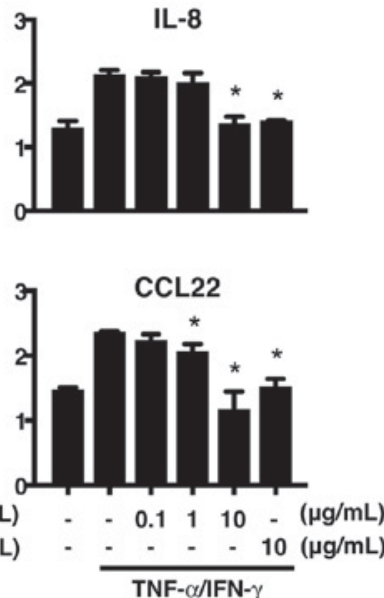

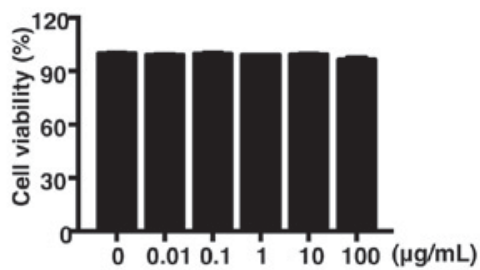

C

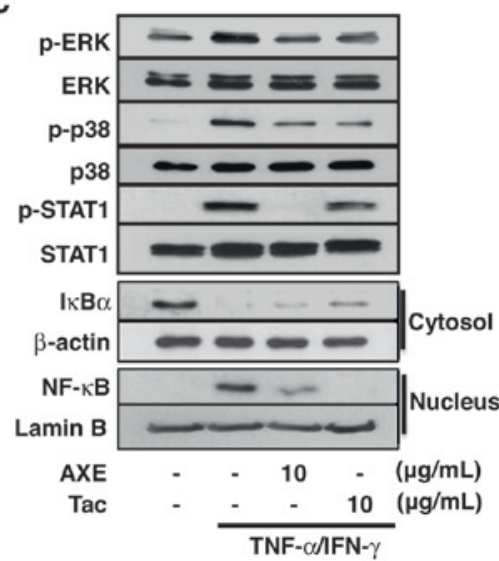

Figure 5. Effects of AXE on TNF- $\alpha / \mathrm{IFN}-\gamma$-stimulated HaCaT cells. Cells were pretreated with AXE or Tac for $1 \mathrm{~h}$ prior to stimulation with TNF- $\alpha(10 \mathrm{ng} / \mathrm{ml})$ and IFN- $\gamma(10 \mathrm{ng} / \mathrm{ml})$. (A) Gene expression of TNF- $\alpha$, IL-1 $\beta$, IL-6, IL-8, CCL17 and CCL22 in HaCaT cells were detected by reverse transcription-quantitative polymerase chain reaction. (B) Cell viability in HaCaT cells following AXE treatment was determined by an MTT assay after $24 \mathrm{~h}$. (C) Representative western

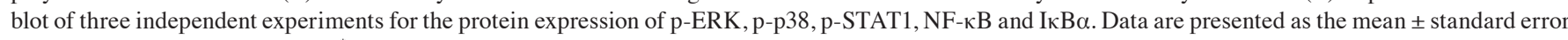
of the mean of five determinants. "P $<0.05$ vs. TNF- $\alpha /$ IFN- $\gamma$ stimulation. AXE, Amomum xanthioides extract; TNF, tumor necrosis factor; IFN, interferon; Tac, tacrolimus; IL, interleukin; CCL, C-C motif chemokine ligand; p-, phosphorylated-; ERK, extracellular signal-regulated kinase; STAT1, signal transducer and

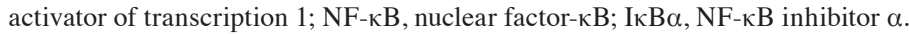

TNF- $\alpha /$ IFN- $\gamma$-induced phosphorylation of ERK, p38 and STAT1, as well as degradation of cytosolic IкB $\alpha$ and nuclear translocation of NF- $\mathrm{kB}$, were inhibited by AXE.

\section{Discussion}

A. xanthioides has been used in Asia to treat various disorders, including stomach and digestive disorders, for a long time (7). The seed of A.xanthioides is listed in the Japanese Pharmacopoeia as 'Amomum seed' (18). Although their total composition remains unclear, the seeds commonly contain five primary classes of components, including volatile oils, saponins, flavonoid glycosides, organic acids and inorganic components (19). Specifically, they contain $1-1.5 \%$ essential oil that is rich in monoterpenoids (borneol, linalool, camphene and nerolidol), which are reported to exhibit numerous 
pharmacological properties, including antimicrobial, anti-inflammatory, anti-oxidant, anti-pruritic, hypotensive and analgesic activities (20).

The present study investigated the pharmacological effects of a water-soluble component of $A$. xanthioides in a mouse AD-like skin inflammation model. AXE alleviated clinical and histopathological alterations in AD-like skin inflammation, including severe ear thickening, ulcers, epidermal thickening and infiltration of immune cells. Gross observation prior to sacrifice demonstrated severe clinical phenotypes, including as hemorrhage, edema, excoriation and scaling in DFE/DNCB-induced skin inflammation. However, the oral administration of AXE ameliorated those symptoms.

The activation of mast cells and eosinophils, and increased IgE levels, are hallmarks of Th2-mediated immune responses $(21,22)$. Mast cells typically accumulate in DFE and/or DNCB-stimulated skin lesions $(23,24)$. They produce histamine, a major contributor to pruritus, which is key symptom of AD (25). Tissue eosinophilia in AD skin is associated with epidermal hyperplasia, spongiosis, skin hypertrophy and disease severity (26). Mast cells and eosinophils express an $\mathrm{IgE}$ receptor (FceRI) on their surface and are activated by $\operatorname{IgE}(21,27)$. In general, the $\operatorname{IgE}$ level is an appropriate marker for Th2 response, whereas IgG2a level is a marker for Th1 response (28). Excessive Th2 responses are primarily observed in the acute stages of AD, whereas a mixed Th1/Th2 pattern of inflammation is usually observed during the chronic stage. Stimulation with DFE/DNCB for 4 weeks induced a chronic AD-like response in the mouse model of our previous study (17). We hypothesize that the suppressive effect of AXE on DFE/DNCB-induced allergic skin inflammation may be due to a decrease in Th2-mediated immune responses leading to a decrease in Th1 responses.

$\mathrm{T}$ cells, as one of the major components of adaptive immunity, have important roles in the pathogenesis of AD. In $\mathrm{AD}$ progression, $\mathrm{T}$ cell polarization is biphasic, primarily involving Th2 cells in the acute phase and Th1 cells in the chronic phase (16). Each subset is characterized by the expression of specific cytokines. Th2-polarized cells express Th2 cytokines, including IL-4 and IL-13 (29), while Th1 cells express IFN- $\gamma$ (30). In addition, Th17 cells, as a specific subset of memory $\mathrm{CD}^{+} \mathrm{T}$ cells, have been reported to contribute to the pathogenesis of AD. Analysis of the IL- $17^{+} / \mathrm{CD} 4^{+}$population in peripheral blood mononuclear cells isolated from patients with AD previously revealed that a higher percentage was present in the severely affected group compared with the healthy control group (31). Furthermore, our previous report demonstrated that all three $\mathrm{T}$ cell subsets increased in draining lymph nodes following DFE/DNCB exposure (14). In the present study, the results indicated that AXE pretreatment in AD rats reduced Th1, Th2 and Th17 subsets in draining lymph nodes. These findings indicate that AXE may control the differentiation of naive $\mathrm{T}$ lymphocytes to effector $\mathrm{T}$ cells.

Various immune biomarkers characterize the inflammatory phenotype of lesional skin in AD. IL-4, IL-13 and IL-31 represent the Th2 response, TNF- $\alpha$ and IFN- $\gamma$ for the Th1 response and IL-17A for Th17 response (32). In the present study, repeated ear skin exposure to DFE/DNCB markedly increased the expression of these biomarkers. IL- 4 and IL-13 are the key upstream drivers of the Th2 response in allergic inflammation.
IL-31 originating from inflammatory infiltrates is considered to be critical in the regulation of keratinocyte differentiation and induction of pruritus in $\operatorname{AD}(33,34)$. As mentioned above, the chronic stage of AD reveals a mixed Th1/Th2 response pattern. IFN- $\gamma$ and TNF- $\alpha$ are secreted by activated Th1 cells and keratinocytes, respectively, and affect the fate of keratinocytes and the skin microenvironment. Overexpression of IFN- $\gamma$ is implicated in skin hypertrophy (35), and TNF- $\alpha$ was reported to induce spongiosis and flatten suprabasal keratinocytes (36). IFN- $\gamma$ produced by Th1 cells promotes the expression of $\operatorname{IgG} 2 \mathrm{a}$ in $\mathrm{B}$ cells (37). IL-17 produced by Th17 cells induces the production of certain cytokines, chemokines and antimicrobial peptides by keratinocytes (38). Therefore, the inhibitory effects of AXE on the expression of each biomarker in DFE/DNCB-treated ear skin may occur due to a decrease in the number and activity of infiltrated immune cells.

Keratinocyte activation in inflamed skin has an important role in the pathogenesis of prolonged inflammatory skin disorders through the regulation of innate immunity (39). Stimulation of epidermal keratinocytes with TNF- $\alpha$ and IFN- $\gamma$ has been reported to induce the expression of various pro-inflammatory cytokines and chemokines, including TNF- $\alpha$ itself, IL-1 and IL-8, and the expression of Th2-attracting chemokines, such as CCL17 and CCL22, was also induced $(40,41)$. These cytokines and chemokines are considered to be important mediators for the development of AD. Cotreatment of keratinocytes with TNF- $\alpha$ and IFN- $\gamma$ was reported to activate several transcription factors, including $\mathrm{NF}-\kappa \mathrm{B}$ and STAT1, through regulation of the MAPK signaling cascade (42). Notably, TNF- $\alpha / \mathrm{IFN}-\gamma$-induced expression of the Th2 chemokines CCL17 and CCL22 was directly altered by specific inhibitors for NF- $\kappa \mathrm{B}$ and STAT (43). Therefore, the inhibitory effects of AXE on TNF- $\alpha / \mathrm{IFN}-\gamma$-stimulated keratinocytes may occur via the suppression of cytokine and chemokine production through the coordination of MAPK, $\mathrm{NF}-\kappa \mathrm{B}$ and STAT1. We hypothesize that AXE may inhibit chronic and self-amplifying loops of immune activation by blocking the activation of keratinocytes and the subsequent production of inflammatory cytokines and chemokines.

In conclusion, the results of the present study demonstrate that oral administration of AXE suppressed DFE/DNCB-induced AD-like skin inflammation, which may occur due to decreased infiltration of immune cells and subsequent Th1/Th2/Th17 responses in $\mathrm{AD}$ skin, and reduced TNF- $\alpha / \mathrm{IFN}-\gamma$-induced immune activation through the regulation of inflammatory cytokines and chemokines in keratinocytes. The present study employed whole aqueous extract of $A$. xanthioides rather than a purified single compound. Therefore, the biological effects of the individual active components are not clear at present. Efforts to identify the active component from AXE on AD symptoms are ongoing in our laboratory. However, the results presented in this report give an insight into the mechanism that is potentially responsible for the anti-AD activity of AXE. Therefore, these results indicate that $\mathrm{AXE}$ may be applied to effectively control $\mathrm{AD}$, as a useful natural pharmacological agent.

\section{Acknowledgements}

The present study was supported by the National Research Foundation of Korea grant funded by the Korean Government 
(grant nos. 2014R1A5A2009242, 2012M3A9B6055416, 2016R1A2B4008513,2017R1D1A1B03031032 and 2015R1D1A3A01016229), the Korea Research Institute of Bioscience and Biotechnology Research Initiative Program (grant no. KGM4251723) and the High Value-added Food Technology Development Program, Ministry of Agriculture, Food and Rural Affairs.

\section{References}

1. Cork MJ, Danby SG, Vasilopoulos Y, Hadgraft J, Lane ME, Moustafa M, Guy RH, Macgowan AL, Tazi-Ahnini R and Ward SJ: Epidermal barrier dysfunction in atopic dermatitis. J Invest Dermatol 129: 1892-1908, 2009.

2. Weidinger S and Novak N: Atopic dermatitis. Lancet 387: 1109-1122, 2016.

3. Sidbury R and Hanifin JM: Old, new, and emerging therapies for atopic dermatitis. Dermatol Clin 18: 1-11, 2000.

4. Vender RB: Alternative treatments for atopic dermatitis: A selected review. Skin Therapy Lett 7: 1-5, 2002.

5. Gardiner P and Kemper KJ: Herbs in pediatric and adolescent medicine. Pediatr Rev 21: 44-57, 2000.

6. Yun Y, Kim K, Choi I and Ko SG: Topical herbal application in the management of atopic dermatitis: A review of animal studies. Mediators Inflamm 2014: 752103, 2014.

7. Quattrocchi U: CRC world dictionary of medicinal and poisonous plants: Common names, scientific names, eponyms, synonyms and etymology. CRC Press, Boca Raton, 2012.

8. Lee YS, Kang MH, Cho SY and Jeong CS: Effects of constituents of Amomum xanthioides on gastritis in rats and on growth of gastric cancer cells. Arch Pharm Res 30: 436-443, 2007.

9. Kim HG, Han JM, Lee JS and Son CG: Ethyl acetate fraction of Amomum xanthioides improves bile duct ligation-induced liver fibrosis of rat model via modulation of pro-fibrogenic cytokines. Sci Rep 5: 14531, 2015.

10. Kim SH and Shin TY: Amomum xanthiodes inhibits mast cell-mediated allergic reactions through the inhibition of histamine release and inflammatory cytokine production. Exp Biol Med (Maywood) 230: 681-687, 2005.

11. Kim SH, Lee S, Kim IK, Kwon TK, Moon JY, Park WH and Shin TY: Suppression of mast cell-mediated allergic reaction by Amomum xanthiodes. Food Chem Toxicol 45: 2138-2144, 2007.

12. Choi EJ, Lee S, Kim HH, Singh TS, Choi JK, Choi HG, Suh WM, Lee SH and Kim SH: Suppression of dust mite extract and 2,4-dinitrochlorobenzene-induced atopic dermatitis by the water extract of Lindera obtusiloba. J Ethnopharmacol 137: 802-807, 2011.

13. Singh TS,Lee S, Kim HH, Choi JK and Kim SH: Perfluorooctanoic acid induces mast cell-mediated allergic inflammation by the release of histamine and inflammatory mediators. Toxicol Lett 210: 64-70, 2012

14. Choi JK and Kim SH: Inhibitory effect of galangin on atopic dermatitis-like skin lesions. Food Chem Toxicol 68: 135-141, 2014.

15. Livak KJ and Schmittgen TD: Analysis of relative gene expression data using real-time quantitative PCR and the 2(-Delta Delta C(T)) method. Methods 25: 402-408, 2001

16. Auriemma M, Vianale G, Amerio P and Reale M: Cytokines and T cells in atopic dermatitis. Eur Cytokine Netw 24: 37-44, 2013.

17. Choi JK, Oh HM, Lee S, Kwon TK, Shin TY, Rho MC and Kim SH: Salvia plebeia suppresses atopic dermatitis-like skin lesions. Am J Chin Med 42: 967-985, 2014.

18. Japan. Kōsei Rōdōshō. Nihon yakkyokuhō=The Japanese pharmacopoeia. Kōsei Rōdōshō, Tokyo, 2001.

19. Wang JH, Wang J, Choi MK, Gao F, Lee DS, Han JM and Son CG: Hepatoprotective effect of Amomum xanthoides against dimethylnitrosamine-induced sub-chronic liver injury in a rat model. Pharm Biol 51: 930-935, 2013.

20. Guimarães AG, Quintans JS and Quintans LJ Jr: Monoterpenes with analgesic activity-a systematic review. Phytother Res 27: $1-15,2013$

21. Kawakami T, Ando T, Kimura M, Wilson BS and Kawakami Y: Mast cells in atopic dermatitis. Curr Opin Immunol 21: 666-678, 2009.

22. Stone KD, Prussin C and Metcalfe DD: IgE, mast cells, basophils, and eosinophils. J Allergy Clin Immunol 125 (2 Suppl 2): S73-S80, 2010
23. Mitchell EB, Crow J, Williams G and Platts-Mills TA: Increase in skin mast cells following chronic house dust mite exposure. $\mathrm{Br}$ J Dermatol 114: 65-73, 1986.

24. Fujii Y, Takeuchi H, Sakuma S, Sengoku T and Takakura S: Characterization of a 2,4-dinitrochlorobenzene-induced chronic dermatitis model in rats. Skin Pharmacol Physiol 22: 240-247, 2009.

25. Yarbrough KB, Neuhaus KJ and Simpson EL: The effects of treatment on itch in atopic dermatitis. Dermatol Ther 26: 110-119, 2013.

26. Simon D, Braathen LR and Simon HU: Eosinophils and atopic dermatitis. Allergy 59: 561-570, 2004.

27. Liu FT, Goodarzi H and Chen HY: IgE, mast cells, and eosinophils in atopic dermatitis. Clin Rev Allergy Immunol 41: 298-310, 2011

28. Adel-Patient K, Créminon C, Bernard H, Clément G, Négroni L, Frobert Y, Grassi J, Wal JM and Chatel JM: Evaluation of a high IgE-responder mouse model of allergy to bovine beta-lactoglobulin (BLG): Development of sandwich immunoassays for total and allergen-specific IgE, IgG1, and $\mathrm{IgG} 2 \mathrm{a}$ in BLG-sensitized mice. J Immunol Methods 235: 21-32, 2000.

29. Brandt EB and Sivaprasad U: Th2 cytokines and atopic dermatitis. Clin Dev Immunol 2: pii: 110, 2011.

30. Zhu J, Yamane H and Paul WE: Differentiation of effector CD4 T cell populations. Annu Rev Immunol 28: 445-489, 2010.

31. Koga C, Kabashima K, Shiraishi N, Kobayashi M and Tokura Y: Possible pathogenic role of Th17 cells for atopic dermatitis. J Invest Dermatol 128: 2625-2630, 2008.

32. Mansouri Y and Guttman-Yassky E: Immune pathways in atopic dermatitis and definition of biomarkers through broad and targeted therapeutics. J Clin Med 4: 858-873, 2015.

33. Cornelissen C, Marquardt Y, Czaja K, Wenzel J, Frank J, Lüscher-Firzlaff J, Lüscher B and Baron JM: IL-31 regulates differentiation and filaggrin expression in human organotypic skin models. J Allergy Clin Immunol 129: 426-433, 433.e1-8, 2012.

34. Raap U, Weißmantel S, Gehring M, Eisenberg AM, Kapp A and Fölster-Holst R: IL-31 significantly correlates with disease activity and Th2 cytokine levels in children with atopic dermatitis. Pediatr Allergy Immunol 23: 285-288, 2012.

35. Jin H, He R, Oyoshi M and Geha RS: Animal models of atopic dermatitis. J Invest Dermatol 129: 31-40, 2009.

36. Danso MO, van Drongelen V, Mulder A, van Esch J, Scott H, van Smeden J and El Ghalbzouri A: TNF- $\alpha$ and Th2 cytokines induce atopic dermatitis-like features on epidermal differentiation proteins and stratum corneum lipids in human skin equivalents. J Invest Dermatol 134: 1941-1950, 2014.

37. Bossie A and Vitetta ES: IFN-gamma enhances secretion of IgG2a from IgG2a-committed LPS-stimulated murine B cells: Implications for the role of IFN-gamma in class switching. Cell Immunol 135: 95-104, 1991.

38. Albanesi C, Cavani A and Girolomoni G: IL-17 is produced by nickel-specific T lymphocytes and regulates ICAM-1 expression and chemokine production in human keratinocytes: Synergistic or antagonist effects with IFN-gamma and TNF-alpha. J Immunol 162: 494-502, 1999.

39. McGirt LY and Beck LA: Innate immune defects in atopic dermatitis. J Allergy Clin Immunol 118: 202-208, 2006.

40. Vestergaard C, Bang K, Gesser B, Yoneyama H, Matsushima K and Larsen CG: A Th2 chemokine, TARC, produced by keratinocytes may recruit CLA+CCR4+ lymphocytes into lesional atopic dermatitis skin. J Invest Dermatol 115: 640-646, 2000.

41. Mizuno K, Morizane S, Takiguchi $\mathrm{T}$ and Iwatsuki K: Dexamethasone but not tacrolimus suppresses TNF- $\alpha$-induced thymic stromal lymphopoietin expression in lesional keratinocytes of atopic dermatitis model. J Dermatol Sci 80: 45-53, 2015.

42. Yang JH, Yoo JM, Cho WK and Ma JY: Anti-inflammatory effects of Sanguisorbae Radix water extract on the suppression of mast cell degranulation and STAT-1/Jak-2 activation in BMMCs and $\mathrm{HaCaT}$ keratinocytes. BMC Complement Altern Med 16: 347, 2016.

43. Jung M, Lee TH, Oh HJ, Kim H, Son Y, Lee EH and Kim J: Inhibitory effect of 5,6-dihydroergosteol-glucoside on atopic dermatitis-like skin lesions via suppression of NF- $\mathrm{BB}$ and STAT activation. J Dermatol Sci 79: 252-261, 2015. 